\title{
Does the Ethnic Composition of Upper Secondary Schools Influence Educational Achievement and Attainment? \\ A Multilevel Analysis of the Norwegian Case
}

Published in European Sociological Review, vol 23, No 3, 2007: 309 - 323

Silje Noack Fekjær, University of Oslo

fekjar@sosiologi.uio.no

and

Gunn Elisabeth Birkelund, University of Oslo

g.e.birkelund@sosiologi.uio.no

Department of Sociology and Human Geography University of Oslo

P.O.Box 1096 Blindern

N-0317 OSLO Norway

Telephone: $\quad+4722855257$

Fax: $\quad+4722855253$

Internet: http://www.iss.uio.no 


\title{
Does the Ethnic Composition of Upper Secondary Schools Influence Educational Achievement and Attainment? A Multilevel Analysis of the Norwegian Case
}

\author{
Silje Noack Fekjær and Gunn Elisabeth Birkelund
}

This article examines the effect of ethnic composition in upper secondary school on students' grades (educational achievement) and their subsequent educational choices (educational attainment), using multilevel analysis. The data set includes all non-vocational students graduating from upper secondary schools in Oslo in 2001, 2002, and 2003, and contains detailed information on individuals' educational choices, grades and ethnic and socio-economic background. We find little evidence of a negative effect of ethnic composition. On the contrary, when we control for academic composition of the schools, we find small, but positive, effects of attending a school with many minority students.

\section{Introduction}

After WWII, most Western societies have experienced a rapid increase in immigration. Norway, a Scandinavian welfare state in the north-western periphery of Europe, is no exception. Today, approximately 6 percent of the population have a non-western immigrant background (Brochmann, 2003; Østby, 2004). This article addresses one aspect of immigration, namely the contextual effects of ethnic minorities in schools on the educational outcome of the students attending these schools.

Since integration and social inclusion are processes that might be expected to take time, a question of vital political interest is how children of immigrants fare in the new society. As was the case in the United States when Europeans arrived more than 100 years ago, newcomers often settle down in disadvantaged areas. The result is housing segregation in the larger cities. In societies like Norway, where equality of opportunity, integration and social inclusion are explicit political goals, ethnic housing segregation causes concern. It implies that immigrant children grow up in segregated neighbourhoods and that local schools become segregated, which might have an impact on children's educational attainment. If immigrant children do not have the same opportunities as native children, the process of integration of newcomers into society is delayed, and new subcultures may emerge, some of which may not be favourable for the future prospects of the immigrant children. Also, and increasingly, a concern has been raised regarding the other children living in these areas, since a large number of immigrant children at school might be affecting the 
educational attainment and future labour market prospects for children of the majority population as well. These concerns seem to build upon a presumption that immigrant children cause difficulties at school and their parents do not have high expectations for their children's future in their new country.

For sociologists, this topic is not new. The early work of James Coleman and his team on equality of educational opportunity related to race in the United States is a classic (Coleman, 1966). We will return to this study later but mention here that the majority of sociological research on this and related topics (such as school effectiveness) is from North America, focusing on race rather than recent immigrants. This perhaps reflects the long tradition of immigration to the United States. Since welfare states differ, the consequences of recent immigration and ethnic school segregation may differ across societies. Also, most previous studies lack appropriate data to properly test contextual effects of schools on individual outcomes. Van der Slik et al. (2006) especially ask for more studies of the effect of ethnic composition on student's motivation and educational achievement in secondary education.

This article will address schooling and ethnic segregation in Oslo, the capital city, where the immigrant population is the highest in Norway. Does the proportion of minority students at a school have an impact on students' educational achievement and their subsequent educational choices? I.e. do students in schools with few minority students benefit from their 'white' surroundings, and if so, does this hold for minority as well as majority students?

We will use register-data information of all students who have completed non-vocational (academic) tracks in upper secondary school in Oslo in the years 2001-2003 (approximately 5,500 students). The data contain detailed individual information about the students' educational choices, grades and their ethnic and socio-economic background. We will distinguish between first and second generations minorities, since difficulties faced by the first group, related to language, lack of knowledge of their new society, etc., are not expected to be similar to those for the second generation, who either were born in Norway, or immigrated before school age. We have generated information on the ethnic and socio-economic composition of all upper secondary schools in Oslo, related to characteristics of the students attending each cohort at each school. Using multilevel analyses we will explore the impact of these school characteristics on the students' educational achievement, i.e. their obtained grades, and their educational attainment, i.e. if they continue to universities or university colleges within one and a half year after their graduation.

The mechanisms related to contextual effects on educational outcomes are likely to be of a general character, yet the strength of their impact may be expected to vary among countries, reflecting how different political regimes have adopted and implemented policies to counteract some of these mechanisms. For the second generation immigrants, we do not expect language difficulties to be of significant importance. Other aspects, such as the educational system (the selection into upper secondary school), the resources distributed to the schools, whether students are differentiated at school by their cognitive skills or not (streaming/tracking), the parental economic resources needed to attend upper secondary schools, etc., are likely to vary substantially among countries, making generalization of our findings more difficult. We would nevertheless expect our findings to be relevant for other countries as well, with some reservations. Given the rather generous economic support of the Norwegian welfare state for first generation immigrants, we would expect our results to be a conservative estimate of the effects of ethnic school segregation on the educational outcomes of immigrant children. On the other hand, immigration from third world countries is a rather recent phenomenon in Norway, and we would not expect the domestic population to be more tolerant than others. Thus, the integration of immigrants in our country might not be more favourable in this respect.

Minority youth have a lower probability of completing upper secondary school than the majority (Fekjær, 2006). Additional analysis of our data (not shown here) shows that in these cohorts in Oslo, 57 percent of majority students have completed nonvocational upper-secondary school, but only 37 percent of second generation ethnic minorities and 20 percent of first generation minority students. Hence, students from the minority group who complete upper secondary school are a more selected group and may have higher educational motivation than majority students. Therefore, our results should not be interpreted as general findings on the importance of ethnic composition in all school types. What we provide is an estimate of the importance of ethnic composition in upper secondary schools where all students who complete (and especially the minority students) are a selected group. The ethnic composition in upper secondary schools has been an important concern in the Norwegian public debate. Whereas compulsory schools (primary and lower secondary level) mainly 
recruit pupils from their neighbourhood areas, the ethnic composition in upper secondary schools has been influenced politically through changing admission rules. In addition, research on the importance of ethnic composition in upper secondary schools is very limited (see subsequently). This means that the subject is of both sociological and social policy relevance.

\section{Immigration in Norway}

In the last decades, Norway has experienced a rapid increase in immigration, especially in the capital city of Oslo. Over a short period (1988-2003), Oslo was transformed from an ethnically homogenous city to having a 17 percent non-western minority (SSB, 2005). Immigrants to Norway comprise labour immigrants from countries that are geographically close (such as Sweden and the other Nordic countries), asylum seekers/political refugees (primarily from Vietnam, Bosnia-Herzegovina, Iraq, Sri Lanka, and Chile) and labour immigrants (in particular from Pakistan and Turkey). With a policy allowing family reunion, the non-western immigrant population grew rapidly during the 1990s (Brochmann, 2003).

Oslo is socio-economically segregated into an eastern and a western part (Hagen et al., 1994). The majority of the immigrant population live in the eastern part where persons with low socio-economic status are concentrated, thus accentuating the differences between the eastern and western parts of the city. There has also been a tendency among the ethnic majority to move out of neighbourhoods with a high proportion of ethnic minority inhabitants (Østby, 2004).

In 1997, the City Council of Oslo introduced a 'freedom of choice' policy for upper secondary schools in Oslo, in such a way that, in contrast to primary and lower secondary schools, students from all over the city could apply to any upper secondary school in Oslo. For some of the less attractive upper secondary school in Oslo this arrangement resulted in a larger proportion of minority students than before. Thus, an unintended consequence of this freedom of choice was increased ethnic school segregation. In 2003, some Oslo schools had more than 55 percent immigrant children. A TV documentary about the ethnic segregation in upper secondary schools in Oslo sparked a public debate on the new 'ghetto schools' in 2003 (TV2, 2003). A number of potential negative aspects of ethnic school segregation were discussed: Language problems (Punjabi was portrayed as the most frequently spoken language at some of these schools), students' lack of motivation, peer groups with negative influence, potential teacher flight away from the 'ghetto schools', lower parent involvement, etc. The political debate resulted in a modified recruitment policy for the Oslo schools, in order to avoid 'ghetto schools.' Thus, the debate on ethnic segregation in schools has been accompanied by a change of policy; yet the actual impact of ethnic segregation in upper secondary schools on the students' educational outcomes in a Scandinavian context is not known. ${ }^{2}$

\section{Ethnic Composition and Educational Outcomes}

The perhaps best known study of ethnic inequality in educational opportunities is the Coleman report and the subsequent debate in the United States. In 1966, James Coleman and his colleagues documented a substantial racial segregation in American schools. The racial composition in a school affected individual outcomes-students who went to predominantly white schools performed better on achievement tests (Coleman, 1966). The message from the Coleman report was that the ethnic composition of the school matters for students' future. Yet, family background was more important: the effect of ethnic composition was to a large degree explained by better educational background and higher educational aspirations in schools with few minority students. The Coleman report caused a lively public debate in the United States and prompted controversial political actions. Mandatory bussing meant that students from black neighbourhoods were sent to white area schools, and vice versa. ${ }^{3}$

The political actions to promote school desegregation prompted a massive body of research on desegregation in the United States. Much of this research dealt with the effect of racial composition of schools on academic achievement. Although the results are somewhat conflicting, most reviewers seem to conclude that attending a desegregated school has a positive effect on the black students' grades and performance on achievement tests, but not for white children (Crain and Mahard, 1983; Wortman and Bryant, 1985; Mayer and Jencks, 1989). This result seems to hold whether schools are 'naturally' desegregated or not. Others concluded that available studies, due to differences in data and methodology, are too inconclusive to state a positive effect of mixed schools on achievement levels (Thomas and Brown, 1982; Hallinan, 2001). A recent Swedish study of 
comprehensive schools does, however, find that the proportion of immigrant students in a school depresses the students' grades, in particular for minority students (Szulkin and Jonsson, 2005). A new Dutch study of language proficiency in elementary school also finds a negative effect of ethnic composition, but this effect is to a large part explained by socio-economic composition (Van der Slik et al., 2006). The authors ask for more research from secondary school and a broader measurement of educational achievement, requirements that seem to be met by our study.

The effect of ethnic composition on educational attainment, i.e. students' subsequent educational choices, has received much less attention than the question of academic achievement. Mayer and Jencks' review (1989) concluded that the evidence on educational attainment is small and conflicting. Jencks et al. (1972) concluded that no effect on educational attainment has been documented, and Crain and Mahard's (1978) results show no clear tendency. However, two recent studies from California found a small negative effect of school segregation on educational attainment, but unfortunately these studies did not include satisfactory controls for individual characteristics, such as socio-economic background (Chang, 2000; Teranishi et al., 2004). In a German study, Kristen (2002) found a negative effect of minority proportion in school on educational attainment, measured as choosing non-vocational tracks ('Hauptschule'), while Dryler (2001) reported the opposite from Sweden: A positive effect of ethnic composition on the probability of continuing in nonvocational tracks in upper secondary school.

Although the results on school achievement is somewhat conflicting and research on educational attainment quite sparse, most studies find a negative effect of a high proportion of minority students both on school achievement and educational attainment. With some exceptions (e.g. Kristen, 2002; Szulkin and Jonsson, 2005; Van der Slik et al., 2006), these questions have received little attention in the recent years and outside of the States, and very few studies focus on the secondary school level.

\section{Why can Ethnic Composition Affect School Achievement and Educational Attainment?}

There are at least two possible explanations as to why ethnic composition effects school achievement and educational attainment. A high proportion of minority students in a school may influence the learning opportunities in the school (Kristen, 2002). School classes with many minority students are likely to have a higher proportion of students with language problems and students with low school performance. The consequence might be that teachers adjust their teaching to the level of these students, and lower their expectations and standards. They may also use a large proportion of their time on the students with extra need for help, thereby neglecting the better students in the class room. In addition, teachers might be less prone to talk about and recommend higher education in a class with a low average achievement level. The mechanism related to teachers' performance in class might be of particular relevance in the Norwegian school system, since, given access to a study programme, all students attend the same classes (i.e. there is no tracking by cognitive abilities). In addition, the best teachers may avoid schools with a high proportion of minorities. This is partly confirmed in a Norwegian study on teacher quality (Bonesronning et al., 2005). However, given the rapid change in the ethnic composition of students in Oslo's schools in the past few years, as a result of policy reforms, we would not expect this mechanism to be particularly strong in this situation.

The other effect of ethnic composition on school achievement and educational attainment relates to peer-groups. Peers affect academic motivation, engagement, and achievement through information exchange, modelling and reinforcement of peer norms and values (Ryan, 2000). Paul Willis' (1977) classic study 'Learning to labour' showed negative attitudes towards schooling among a group of working-class boys in an English school. This study contested the belief that 'everybody does their best in school, all the time'. The boys in Willis' study did not have education as their primary goal in life, but valued a working-class culture instead; a rational adaptation, perhaps, to a society from which they had learned (from parents and others) not to expect fairness and equality of opportunity. ${ }^{4}$ If there are more students with attitudes like this in schools with high proportions of ethnic minorities, this might influence the peer environment and lower the educational aspirations of the students in general.

A prerequisite for negative peer-group influence would be that minority youth have lower educational aspirations and reveal more negative attitudes to school than other students. But is this really the case? Previous studies suggest rather contrary: Norwegian ethnic minority youth express high educational aspirations, especially taken their low 
socio-economic background into account (Lauglo, 2000). High motivation among minority youth might partly be due to expectations from their parents, whose immigration often was motivated by a wish to create a better life for the next generation (Ogbu, 1991; Portes and Rumbaut, 2001). Ogbu (1991) argues that it might be useful to distinguish between involuntary minorities and the new immigrants. Involuntary minorities, such as blacks in the United States, have for generations experienced suppression, and might therefore be less likely to expect fairness and recognition within the educational system and the labour markets; whereas the new immigrants often come to their new country with a positive attitude to education and a positive motivation for mobility. Thus, findings from previous American studies on the impact of race may not be relevant for the more recent immigrants. Schools with high proportions of ethnic minority youth may just as well have a peer environment where education is highly valued.

Although the effect of peer environment on students' achievement and educational attainment is not clear, the argument related to lower learning opportunities in schools with high proportion of minority students leads us to expect lower school achievement and a smaller proportion of students seeking higher education in schools with a high proportion of ethnic minorities.

We will also explore if there are any threshold effects of ethnic concentration. Some studies have found a threshold, such as a Swedish study of comprehensive schools, showing a threshold at 40 percent (Szulkin and Jonsson, 2005: 36). This threshold effect is moderately strong and concerns rather few schools, yet it affects 14 percent of the immigrant children.

A long research tradition has documented lower school achievement and educational attainment among students from low socio-economic background (see for instance Bourdieu, 1984; Shavit and Blossfeld, 1993; Erikson and Jonsson, 1996; Hansen, 1997). Previous Norwegian research have documented that first generation immigrants in Norway have had difficulties related to employment and income, and are lower educated than the majority (Østby, 2004). Thus, we expect minority students to be overrepresented among families with low socio-economic resources. Schools with many minority students may also have many majority students with low socio-economic resources. This means that a possible negative effect of ethnic school composition on educational outcome might be due to the socio-economic composition of the schools. We will measure the academic composition of schools, i.e. the proportion of parents with an academic education, and we expect the effect of schools' ethnic composition on students' achievement and attainment to diminish when we control for the academic composition of the schools.

Earlier in this article, we argued that the effect of ethnic school composition would be similar for majority and minority students. This expectation should be modified. Previous research has found that attending a school with a high proportion of your own ethnic group has a positive effect on school attachment (Johnson et al., 2001). Therefore, attending a school with high proportion minority students would be positive for the minorities, but not for the majority students. For minority students, contact with other students in the same ethnic group prevents 'dissonant acculturation', which has been described as a process where the younger generation distances itself from the culture of their family's country of origin and instead seeks a western lifestyle, which often is associated with revolt and disrespect for traditional values supporting family cohesion, school motivation, and work ethics (Portes and Rumbaut, 2001). Thus, minority students would be better off in schools with a high proportion of minority students.

Borjas' term 'ethnic capital' gives another possible explanation for a positive effect of attending a school with many of one's own ethnic group. Ethnic capital is the joint resources of an ethnic group, expected to be advantageous for the individual members of the group, and frequent contact with the group may give access to these resources (Borjas, 1992). We would also like to mention the problem related to social identity, i.e. the labelling by others as being a member of a minority group. As argued by Moss Kanter (1977) minorities are usually regarded as representatives ('tokens') of their group, not as individuals. This changes when the proportion of minorities increase. Thus, when the number of one category of people increases in a group, they are no longer seen as 'tokens'. This eases the performance pressure and softens group boundaries and role entrapment. Kanter's focal point was gender relations. But if a similar mechanism applies to ethnic minorities, we can expect that attending a school with many minority students might make it easier being a minority student, partly because they will be treated more as individuals and less as 'tokens'.

Borjas', Portes and Rumbaut's as well as Kanter's arguments give reasons to expect that a possible negative influence of a high proportion of minorities in a school might be less pronounced or even positive for students with a minority background. On the other hand, previous studies have found that the effect of ethnic composition is smaller for majority youth, 
at least when it comes to school achievement (Crain and Mahard, 1983; Wortman and Bryant, 1985; Mayer and Jencks, 1989). We would expect a positive influence of attending a school with a high proportion of minorities for minority youth, while we expect to find a negative effect for the majority students.

Up till now, we have concentrated on the contextual effects of ethnic school composition on individual educational outcomes. These compositional effects ought to be separated from selection effects, related to the schools' ability to recruit motivated students. Some schools are more prestigious than others (for a variety of reasons). Schools that recruit a high proportion of students with poor grades are less likely to have high achieving students and students with high motivation for continuing with higher education. We also know that minority students and students with low socio-economic background are more likely to receive poor grades than others, partly due to their family background (Bakken, 2003). Thus, selection effects related to previous school performance and socio-economic background needs to be taken into consideration when we estimate a possible effect of ethnic composition of the schools on the student's educational achievement. Lack of control for selection effects has been a major problem in many previous studies on school effects on individual outcome (Crain and Mahard, 1978; Rutter and Maughan, 2002). Unfortunately, our data do not include information on primary school grades. But we do have the possibility of controlling for individual characteristics, such as parent's educational level, and in the analyses of educational attainment also grades from upper secondary school. We expect control for individual characteristics to reduce the effect of the schools' ethnic composition on individual school achievement and educational attainment.

Previous studies of school compositional effects have been criticized for two sorts of methodological problems, one related to selection and one to distribution of resources. The selection problem relates to the sorting of families into neighbourhoods, which might be the expected behaviour of ambitious parents in a system with few private schools such as the Scandinavian. If (some) families in Oslo move to areas where they expect to find the best schools, the local schools contain a proportion of parents who have actively selected themselves into these school districts due to unmeasured characteristics (ambition on behalf of their offspring), characteristics that are likely to be associated with their children's educational outcomes. ${ }^{5}$ Since we look at schools that recruit students under the 'freedom of choice' doctrine, parents' selection of housing due to the reputation of the local schools, are less problematic for our study. Similarly, as mentioned earlier, if the reputation of schools as 'good' or 'less good' hinges on the teachers' performance and quality, the rapid changes in the recruitment policy and thus the student composition of the upper secondary schools should not cause dramatic changes in the recruitment of 'good' or 'less good' teachers to the Oslo schools.

Another problem of previous studies relates to the unequal distribution of resources among schools. If some schools are better equipped, in terms of library and laboratory facilities, etc., this might also have a bearing on the students' achievement. In Oslo, however, all the upper secondary schools are fully publicly financed by the same local authorities. Thus, differential distribution of resources among the schools is less likely to be a serious problem. All in all, we believe that the biases often found in previous studies of contextual school effects are not representing similar challenges for our study.

\section{Data and Methods}

Register-data from Statistics Norway and higher educational institutions in Norway are combined to gain detailed information on the students' country of origin (parents' or own place of birth), time of immigration (distinguishing first and second generation immigrants), school, grades, and socio-economic background. The analyses in this article include all students who graduated from upper secondary schools in Oslo, on the non-vocational tracks, ${ }^{6}$ in 2001, 2002, and 2003.

Altogether we have 25 schools included in our analyses. $^{7}$ We excluded schools with less than 25 graduates per year, because the ethnic composition in small schools will be quite arbitrary. We also excluded one school for students with special needs and persons who received upper secondary diplomas from adult training programmes.

At the individual level, we have excluded persons who lack information on school (1.2 percent). For 23 percent of the sample there is no information on grades. These students have therefore been omitted from the analyses of educational achievement, but they are included in the analyses of educational attainment. To check for bias the analyses on educational attainment are tested also when those with lacking information on grades are excluded. This does not alter the main results. 
The analyses on educational achievement include graduates from the years 2001-2003 $(N=5,508)$, while the analysis on educational attainment include only graduates from the years 2001 and $2002(N=4,656){ }^{8}$ The reason for this discrepancy is that Norwegian students often take a year or two off before they continue to higher educational institutions after they have completed their upper secondary education. Many travel (often world wide), many take a job before they decide what to do next, and quite a few (mostly men) join the military forces for a year. Since we wanted a time span of minimum one and a half year before we measure if the students have started at universities or colleges, graduates from 2003 are excluded from the second analyses.

\section{Measurements}

We have a multilevel research design, which implies that we need information on both individual level variables (level 1) and school level variables (level 2). The dependent variables are at level 1 .

\section{Dependent Variables}

The first dependent variable is educational achievement, i.e. school grades at graduation, an index that includes all grades that count when students apply for entry into higher education. These are the grades that will be important for the student's further life-chances. We note from Table 1 that minority students, in particular first generation minority students, achieve lower grades than majority students, but the differences are not large.
In addition to being a dependent variable in the first analyses, grades from upper secondary school are also an independent variable in the second analyses, of educational attainment. We have standardized this variable, with zero mean and a standard deviation of one.

The second dependent variable, educational attainment, measures whether the students have registered in a university or college within one and a half year after graduation from upper secondary school. 66 percent of our sample of 2001 and 2002 graduates has registered in higher education within one and a half year after graduation from upper secondary school. ${ }^{9}$ Table 1 shows that continuing to higher education is a bit more common among graduates with minority background than among the majority students.

\section{Explanatory Variables: Level 2-School Characteristics}

By aggregating characteristics related to each cohort of students attending each school we have generated two school characteristics (level 2 variables): the ethnic composition and the academic composition of the schools. The ethnic composition measures the proportion of non-western ethnic minorities among the students who graduated from non-vocational tracks in the school the same year. Between 0 and 59 percent of non-western minorities graduated from these schools between 2001 and 2003. Table 1 shows that majority students attend schools with an average of about 14 percent non-western students, compared to minority students, who attend schools with about 25 percent (first generation) and

Table 1 Descriptive statistics

\section{Majority mean (SD)}

\section{1. generation minority mean (SD)}

$42.8(6.4)$

Educational achievement (grades)

Ethnic composition of school (non-western)

Academic composition of school (parents higher education)

Age (at graduation)
$13.8(11.2)$

$67.2(16.1)$

$19.1(0.9)$
$38.9(6.4)$

$24.5(14.4)$

$58.4(16.8)$

19.9 (1.6)
2. generation minority mean (SD)

$15.7(12.9)$

$26.9(16.1)$

$54.9(17.7)$

$65.4(16.9)$

$19.3(0.7)$

$19.2(0.9)$

\begin{tabular}{lllll}
\hline $\begin{array}{l}\text { Educational attainment } \\
\quad \% \text { started in higher education) }\end{array}$ & 64.5 & 75.3 & 76.0 & 66.2 \\
$\begin{array}{l}\text { Parents education } \\
\quad \% \text { higher educated })\end{array}$ & 71.8 & 23.2 & 32.6 & 65.3 \\
$\begin{array}{l}\text { Gender (\% female) } \\
N(\%)\end{array}$ & 54.9 & 55.2 & 55.6 & 55.0 \\
& $6,007(84.2)$ & $272(3.8)$ & $851(11.9)$ & $7,130(100)$ \\
\hline
\end{tabular}


27 percent (second generation) non-western minority students.

Academic composition is measured as the proportion of students who have at least one parent with academic education (college or university education) among the students who graduate from non-vocational tracks in a school in the same year. As can be seen from Table 1, the majority students attend schools where on average 67 percent of the students have parents with academic education, the first generation minority students attend schools with an average value of 58 percent, and the second generation minority students attend schools with an average academic composition of 55 percent.

Schools with many minority students have fewer students with academically educated parents. This implies that the school variables are highly negatively correlated (Pearsons $R=-0.69$ ). Since this correlation is rather strong, we may have problems with colinearity in the models, so that the variables may confound the effects of each other. We will, therefore, introduce them one at a time into the equations, and pay special attention the possible changes in the individual effects for the variables as well as their standard errors. We have standardized ethnic composition and academic composition (with mean $=0$ and standard deviation $=1$ ).

\section{Explanatory Variables: Level 1-Individual Characteristics}

Individual ethnicity is divided into three groups: ethnic majority (84 percent, including a small group of western minorities), first generation non-western minorities (4 percent) and second generation nonwestern minorities (12 percent). This classification conceals differences within the minority groups. Previous research (Fekjær, 2006) and additional analyses of the data in this article show that both educational achievement and educational attainment varies between minority groups with different countries of origin. Due to limitations of the sizes of the different groups in our data on Oslo schools, we have decided to merge all minority groups into two groups, only differentiating between their statuses as first and second generation immigrants. We have, however, tested our analyses with control for country of origin, and find that although there are clear differences between the minority groups, controlling for country of origin does not alter the contextual effect of ethnic composition in school.

Parents' education is measured when the students are aged $16 .{ }^{10}$ We use the official classification of education, which measure highest level of education and we distinguish between four levels, compulsory school or less, upper secondary school, bachelor level, and master level. Nearly 72 percent of the majority students have at least one parent with academic education, compared to only 23 percent of first generation minorities and 33 percent of second generation minority students. We include gender and age as control variables. Gender is coded 0 (male) and 1 (female). Age is coded 0 (19 years of age), 1 (20 years of age), etc.

\section{Methods}

We want to explore a multilevel proposition: a macrolevel variable (ethnic composition of schools) has a possible effect on micro-level variables (grades and educational attainment), controlling for another macro-level variable (academic composition of schools) and other micro-level variables (e.g. parents' education). We, therefore, apply multilevel linear regression for the analyses of educational achievement (i.e. grades), and multilevel logistic regression for the analyses of educational attainment (i.e. higher level education). Multilevel analyses are recommended when the proposition is multilevel, since uni-level analysis including variables from the macro-level are likely to result in biased and typically over-optimistic significance tests (Goldstein, 1997; Snijders and Bosker, 1999)..$^{11}$

The models presented are hierarchically organized. We start by modelling a zero-model, M0, with only the intercept, in order to get a measure of the error terms. Next, M1 includes individual ethnicity and ethnic composition, M2 adds academic composition, M3 adds individual characteristics, and M4 includes interaction terms of individual ethnicity and ethnic school composition, in order to test for different contextual effects for minority and majority students. ${ }^{12}$

\section{School Effects on Educational Achievement}

Table 2 shows Models 0-4 addressing the students' grades. Looking at the model fits (-2LL change), we find that all model changes are significant. The last model, Model 4, which introduced the interaction term to check if the ethnic composition of the schools had a differential impact on the minority and majority students, gives only a small improvement over Model 3 ( $-2 \mathrm{LL}$ change is significant at 5 percent but not at 1 percent level). 
Table 2 The effect of ethnic composition of schools on educational achievement (students' grades)

\begin{tabular}{|c|c|c|c|c|c|}
\hline Fixed effects & $\begin{array}{l}\text { Model } 0 \\
\text { Coefficient } \\
\quad \text { (SE) }\end{array}$ & $\begin{array}{c}\text { Model } 1 \\
\text { Coefficient } \\
\text { (SE) }\end{array}$ & $\begin{array}{l}\text { Model } 2 \\
\text { Coefficient } \\
\text { (SE) }\end{array}$ & $\begin{array}{l}\text { Model } 3 \\
\text { Coefficient } \\
\text { (SE) }\end{array}$ & $\begin{array}{l}\text { Model } 4 \\
\text { Coefficient } \\
\text { (SE) }\end{array}$ \\
\hline Intercept & $-0.15(0.06)$ & $-0.06(0.05)$ & $-0.03(0.04)$ & $-\mathbf{0 . 4 3}(0.05)$ & $-0.43(0.05)$ \\
\hline Ethnic composition & & $-0.09(0.05)$ & $\mathbf{0 . 1 3}(0.05)$ & $\mathbf{0 . 1 0}(0.05)$ & $\mathbf{0 . 1 2}(0.05)$ \\
\hline 2. gen. $\min$ & & $-\mathbf{0 . 3 5}(0.04)$ & $-0.36(0.04)$ & $-0.19(0.04)$ & $-\mathbf{0 . 1 8}(0.05)$ \\
\hline 1. gen. min. & & $-0.55(0.06)$ & $-\mathbf{0 . 5 5}(0.06)$ & $-0.23(0.07)$ & $-0.12(0.08)$ \\
\hline Academic composition & & & $0.33(0.06)$ & $\mathbf{0 . 2 3}(0.05)$ & $\mathbf{0 . 2 3}(0.05)$ \\
\hline Parents' edu. 1 ( $0=$ comp edu $)$ & & & & $\mathbf{0 . 1 2}(0.04)$ & $\mathbf{0 . 1 2}(0.04)$ \\
\hline Parents' edu. 2 & & & & $0.31(0.04)$ & $0.31(0.04)$ \\
\hline Parents' edu. 3 & & & & $\mathbf{0 . 5 8}(0.04)$ & $0.58(0.04)$ \\
\hline Gender $($ male $=0)$ & & & & $0.14(0.03)$ & $0.13(0.03)$ \\
\hline Age $(0=19)$ & & & & $-0.12(0.02)$ & $-0.14(0.03)$ \\
\hline 2. gen*etn.comp & & & & & $-0.02(0.03)$ \\
\hline 1. gen*etn.comp & & & & & $-0.16(0.06)$ \\
\hline
\end{tabular}

Random effects

Parameter (SE) Parameter (SE) Parameter (SE) Parameter (SE) Parameter (SE)

\begin{tabular}{lccccc}
\hline Sigma u & $0.18(0.03)$ & $0.15(0.03)$ & $0.09(0.02)$ & $0.08(0.02)$ & $0.08(0.02)$ \\
Sigma e & $0.83(0.02)$ & $0.81(0.02)$ & $0.81(0.02)$ & $0.77(0.02)$ & $0.77(0.02)$ \\
$N$ & 5,508 & 5,508 & 5,508 & 5,508 & 5,508 \\
$-2 \mathrm{LL}$ & $14,804.420$ & $14,657.780$ & $14,630.110$ & $14,319.240$ & $14,311.660$ \\
\hline
\end{tabular}

Note: Results that are significant on a 5 percent level are in bold.

The interclass correlation coefficient (ICC) for the first model, Model 0 , Table 2, is 18 percent $[0.18 /$ $(0.83+0.18)]$; i.e. schools account for 18 percent of the variability of grades. This gives empirical support for using a multilevel model instead of an ordinary regression model. Table 2 also shows that the unexplained variance in grades between students from the same schools (within school variance, sigma $e$ ) is far greater than the variance between schools (sigma $u$ ). These results are supported by previous comparative research, showing that Norway is marked by a comparatively low variance in school performance between schools (PISA, 2004).

In model 1, we introduce individual ethnicity and the ethnic composition of schools to see if students from schools with a high proportion of minorities receive poorer grades. Model 1 shows that the ethnic composition of the schools does not have a significant effect on academic achievement, yet it is negative, as expected, and close to significance. Model 1 also shows that students with ethnic minority background have lower grades than the majority group, in particular the first generation do less well in school.

Model 2 introduce the academic composition of the schools. We now see that the first model had compressed an effect of ethnic composition.
In Model 2, both the effect of ethnic composition and the effect of academic composition are positive. Thus, if schools had been similar with regard to parents' background, ethnic composition has a positive, and not as expected, negative, impact on the student's grades. The size of the effect is not very large, yet it is noticeable. Controlling for academic composition, students from a school with only majority students have a grade average which is $3 / 4$ standard deviations lower than students from a school with 40 percent minority students. The academic composition of the schools also has, as we might expect, a positive effect on the students' school achievement, independent of ethnic composition. Students from schools with a high proportion of well-educated parents receive better grades, irrespective of ethnic composition.

Individual characteristics are included in Model 3; and in Model 4 we introduced interaction terms for individual ethnicity and ethnic composition of schools. If schools with high proportion of minority students are 'good' for minority students (first and second generation) we would expect positive interaction terms compared to the reference category, which is the majority students. The results show little support for this hypothesis. Model 4 shows that controlled for various school and individual characteristics, there is 
no significant difference in the effect of ethnic composition on grades for second generation minority students, compared with the majority. For first generation minority students the interaction term is negative and significant. This means that the positive affect of ethnic composition that we find among the majority and second generation minorities does not yield for first generation minorities.

Turning to the other effects in Models 3 and 4, we find a strong positive gradient related to parents' education. The better educated the parents are, the better the students' grades. Girls receive better grades than boys. Postponing upper secondary education seems to have a small negative effect on achievement, as the older students have lower grades than those who graduated as scheduled at the age of 19 . We also note that the effects of the school variables change slightly with the introduction of individual characteristics of the students, yet the main patterns remains the same.

In short, when we look at educational achievement, none of our expectations are sustained. Students from schools with a high proportion of ethnic minorities do not have lower educational achievement than other students (we should add, though, that this coefficient is negative and borderline to significance). Although there is a high correlation between ethnic composition and academic composition, we do not find that the (non-significant) effect of ethnic composition diminish when we control for the academic composition of the schools, rather contrary, it increases and becomes positive. We do not find a positive influence on educational achievement for minority students attending a school with high proportion minority students. Rather, for first generation immigrants, we find a negative effect. And finally, we do not find a reduced effect of ethnic composition after we control for individual characteristics.

\section{School Effects on Educational Attainment}

Turning to educational attainment, we note from Model 1 in Table 3 that the effect of ethnic composition of the schools is small and not significant. ${ }^{13}$ We also note that both first and second generation minorities have a higher probability to continue into higher education than majority students have. When we introduce academic composition in Model 2, we find, as in Table 2, that the effect of ethnic composition becomes significant, and positive. Students from schools with a high proportion of ethnic

Table 3 The effect of ethnic composition of schools on educational attainment (students' probability to continue to universities/colleges)

Fixed effects

\begin{tabular}{|c|c|c|}
\hline $\begin{array}{l}\text { Model } 0 \\
\text { Coefficient }\end{array}$ & $\begin{array}{c}\text { Model } 1 \\
\text { Coefficient }\end{array}$ & $\begin{array}{c}\text { Model } 2 \\
\text { Coefficient }\end{array}$ \\
\hline
\end{tabular}

(SE)

(SE)

(SE)

(SE)

(SE)

\begin{tabular}{|c|c|c|c|c|c|}
\hline Intercept & $0.53(0.10)$ & $0.46(0.10)$ & $\mathbf{0 . 5 6}(0.08)$ & $0.68(0.14)$ & $\mathbf{0 . 6 8}(0,14)$ \\
\hline Ethnic composition & & $0.05(0.09)$ & $0.45(0.11)$ & $0.26(0.11)$ & $0.23(0.11)$ \\
\hline 2. gen. $\min$ & & $0.56(0.11)$ & $0.58(0.11)$ & $1.14(0.16)$ & $1.04(0.19)$ \\
\hline 1. gen. min. & & $0.48(0.17)$ & $\mathbf{0 . 5 0}(0.18)$ & $1.11(0.25)$ & $1.05(0.30)$ \\
\hline Academic composition & & & $0.54(0.10)$ & $0.31(0.10)$ & $0.30(0.10)$ \\
\hline Parents' edu. $1(0=$ comp edu $)$ & & & & $0.04(0.14)$ & $0.04(0.14)$ \\
\hline Parents' edu. 2 & & & & $0.06(0.13)$ & $0.06(0.13)$ \\
\hline Parents' edu. 3 & & & & $0.32(0.14)$ & $\mathbf{0 . 3 2}(0.14)$ \\
\hline Gender $($ male $=0)$ & & & & $\mathbf{0 . 2 2}(0.08)$ & $\mathbf{0 . 2 2}(0.08)$ \\
\hline Age $(0=19)$ & & & & $0.11(0.06)$ & $0.11(0.07)$ \\
\hline Grades & & & & $0.57(0.05)$ & $\mathbf{0 . 5 7}(0.05)$ \\
\hline 2. gen*etn.comp & & & & & $0.13(0.14)$ \\
\hline 1. gen*etn.comp & & & & & $0.09(0.25)$ \\
\hline
\end{tabular}

Random effects

Parameter (SE) Parameter (SE) Parameter (SE) Parameter (SE) Parameter (SE)

\begin{tabular}{lccccc}
\hline Sigma u & $0.40(0.09)$ & $0.39(0.09)$ & $0.23(0.06)$ & $0.10(0.04)$ & $0.10(0.04)$ \\
$N$ & 4,656 & 4,656 & 4,656 & 3,584 & 3,584
\end{tabular}

Note: Results that are significant on a 5 percent level are in bold. 
minorities seem to have higher motivation for university or college education than students from schools with low proportion of minorities. The difference is not negligible: calculated under the assumption that 50 percent of the parents have higher education, majority students from a school where 20 percent of the students belong to an ethnic minority would have a 55 percent probability of starting in higher education compared to a 71 percent probability for students from a school where 40 percent of the students belong to an ethnic minority.

Moving to Models 3 and 4, we find a slightly different pattern than previously. After we introduced the individual level variables the effect of both the ethnic and the academic composition diminish. We also note that the effect of individual ethnicity is stronger in Models 3 and 4, indicating that if students had been similar with regard to their socio-economic background and their grades from upper secondary school, the difference between majority and minority students in the likelihood of continuing into universities and colleges would be larger, with minorities having the highest probability to continue. Not surprisingly, we see a positive effect of having good grades on educational attainment. Girls are more likely than boys to seek higher education. Having parents with university or college education increases the probability of starting in higher education. Looking at the interaction terms, in Model 4, we find that they are not significant. Thus, the positive effect on educational attainment of attending a school with high proportion of minority students is similar for majority and minority students.

We have also tried to look for threshold effects of ethnic composition on students' educational outcomes, without success. Quadric terms of ethnic composition are insignificant in all models, and this yields both for analyses on grades and educational outcomes. We have also looked for non-linear effects by testing dummy variables (minority proportion above 10, 20, 30, 40, and 50 percent) and plots of Model 1. Our conclusion is that the effect of ethnic composition seems to be linear, as we can find no proof of thresholds effects.

To sum up our results on educational attainment we find again that most of our expectations are not sustained. Students from schools with a high proportion of ethnic minorities do not seek higher education to a lower degree. The effect of ethnic composition does change as expected when we control for academic composition, however, it becomes positive and significant. The effect of ethnic composition on students' educational attainment does not differ for minority and majority students. We also expected a reduced effect of ethnic composition when we controlled for individual characteristics, and this is confirmed, although the effect of ethnic composition has a different sign than expected.

\section{Discussion}

Our main finding is that there is no negative effect of ethnic composition in upper secondary schools on students' educational achievement and attainment. ${ }^{14}$ When we control for academic composition we find small, but positive, effects of ethnic composition. This result comprises both majority students and second generation minority students. Among the first generation minorities we find a negative effect of ethnic composition on educational achievement, but no effect on educational attainment.

We argued above that ethnic composition would have an impact on the learning environment in the classrooms in such a way that a high proportion of minority students would lower both the quantity and the quality of teaching. A prerequisite for this argument is that minority students are low achieving, compared to the ethnic majority. We have seen that the achievement differences between the minority and the majority are quite small among students at this level. Also, it seems that some of the effects related to teachers' performance might just as well be opposite: Teachers in schools with a high proportion of ethnic minorities might encourage further education because they are aware of the under-representation of minorities in higher education. Obviously, this is an area that calls for more research.

Another reason to expect a negative effect of ethnic composition was related to peer effects. However, previous research has found positive attitudes towards education among Norwegian ethnic minorities, a fact that undermines this argument. Since a smaller proportion of the minorities complete upper secondary school compared to the majority, these minority students are more selected and most likely more positive towards education than the other students. The selection of minority students who complete upper secondary school might explain why we get positive effects, and not as expected negative effects, of individual minority status on educational attainment. There seems to be stronger polarization in education among ethnic minorities in Norway: A majority end up with only compulsory education and/or vocational education, whereas for those who complete the nonvocational secondary track a relatively high proportion continue to (and complete) university or college 
education (Fekjær, 2006). Minority students who complete upper secondary school seem to be a strongly selected group, with high educational motivation and attainment. This means that our results from upper secondary schools should not be generalized to other schools. ${ }^{15}$ Ethnic composition may have a different impact when we look at schools where the minority students are a less selected group.

Previous research has shown that the effect of ethnic composition interacts with individual characteristics such as social background (Portes and Hao, 2004). Hence, one could argue that the effect of ethnic composition is dependent on the students' ability and motivation. Our sample comprise students who have completed 12 years of schooling, thus we can presume that they are highly motivated for schooling, in addition to the fact that they are relatively high performing. This may be why the ethnic composition of these schools might be less important than if we had focused on lower level schools.

\section{Conclusion}

The results obtained in our analyses diverge from what has been portrayed as a public challenge related to the problems of the so called 'ghetto-schools' in Oslo. There are indications that some ethnic Norwegians are worried about the impact of ethnic minorities on their children's performance in school. For upper secondary schools, they need not worry. Ethnic composition in upper secondary schools does not negatively influence school achievement and educational attainment; thus, avoiding schools with a high proportion of minority students, because of their ethnic composition, does not seem to be a necessary strategy for those who want to ensure educational success for their children.

Our data have, however, revealed a strong relationship between the ethnic composition and the academic composition of upper secondary schools in Oslo, in such a way that schools with high proportion ethnic minorities also have high proportion of students with parents with low levels of education. Academic composition has an effect on educational outcomes, independent of ethnic composition. We also find that for both minority and majority students, their home environment is important. This means that if a student belongs to a school where most parents do not have higher education, and the student in addition comes from a home where none of his/her parents have higher education, this student is likely to receive lower grades, independent of his/her own ethnic identity and independent of the school's ethnic composition.
Thus, rather than worrying about the ethnic composition of upper secondary schools, politicians ought to consider establishing recruitment rules for the schools that reduce inequality related to the students' family background.

Since we are addressing recent immigrants to a Scandinavian welfare society, we should perhaps not be surprised that our results differ from previous US research. Black students in American schools, which for generations have experienced suppression, can be expected to be less likely to expect fairness and recognition within the educational system. The new immigrants, however, often come to their new country with a positive attitude to education and a positive motivation for mobility. Nevertheless, we also find large selection effects in the Norwegian educational system. In these cohorts, 63 percent of second generation minority students and 43 percent of the majority students do not complete non-vocational tracks in upper secondary school. For some of these groups, peer effects related to 'learning to labour' might be relevant; i.e. negative educational motivation.

Cultural complexity is growing in our societies, and exposure to different ethnic groups at school may be a valuable experience for the students in their future life. Thus, for students both at predominantly 'white' schools and at schools more dominated by minorities, a recruitment policy that resulted in more mixed ethnic schools might be favourable for all.

\section{Notes}

1. From 1997-2005 place of residency has only been important for assignment of pupils to primary and secondary schools, but from 2005 and onwards the local address will again be of significance also for admission to upper secondary school in Oslo (Oslo kommune, 2005). Since there are no school districts where immigrants comprise the majority of the citizens (Østby, 2004; Oslo kommune, 2005), this rule limits the possibilities for 'ghetto schools'.

2. The few studies of ethnic composition in Scandinavia are all focused on compulsory school. Engen et al. (1997) include ethnic composition in their study of minority students performance in Norway, but since there are no control for socio-economic composition, the data is rather old (1993-94) and the sample is narrow and do not include majority students, their study is of limited interest for answering the questions in this 
article. Dryler (2001) studies the effect of ethnic composition in compulsory school on grades and choice of upper secondary school in Sweden, but does not include further educational choices and whether the effects differs between ethnic groups. Szulkin and Jonsson (2005) analyse the impact on ethnic school segregation on students' educational outcomes, using Swedish data. Although their results are from comprehensive school, this study is of high relevance and will be described further in the next section.

3. The children of the second author of this article experienced bussing in the United States during my research period in Berkeley, California in the mid-1990s. We lived in a mostly white middleclass neighbourhood, and my children were bussed to a school in an area of the city with a predominantly black neighbourhood. Since most US white children at their age seemed to be registered at private schools, the public schools were strongly segregated. The unintended consequences of bussing (such as increased attendance at private schools) is an interesting topic, but cannot be discussed here.

4. Confer the parallel in this argument to experiences of the blacks in the United States.

5. Szulkin and Jonsson (2005) include information on families' geographical moves and find no significant selection effects in their study of Swedish comprehensive schools.

6. Although students from vocational tracks since 1994 have been eligible for higher education if certain demands are met, they are omitted from the analysis. A main reason for this is that since students from vocational tracks are in training the last year of schooling, the majority lacks information on school and grades. In addition, relatively few of the students graduating from vocational tracks continue to higher education (7 percent within the first 1.5 years). The largest nonvocational track is the academic track. Nonvocational tracks also include 'music, dance and drama', 'sports' and 'media and communication', tracks which contain academic subjects so that students from these tracks also can pursue higher education at colleges and universities. We have performed separate analyses where we excluded students from these 'semivocational' tracks, without obtaining any different patterns.

7. Because we measure ethnic composition for each cohort at each school separately, our total $N$ of schools is not 25, but 73 (analyses of educational achievement) and 49 (analyses of educational attainment). Students from schools with less than 25 students comprise only 1.9 percent of the original sample.

8. Since the descriptive statistics are very similar when we exclude those with missing information on grades or those graduating in 2003, we only display results for graduates from 2001-2003 including students with missing information on grades. This explains the large $N$ in Table 1 .

9. In Norway, unskilled labour is the only alternative to continuing in higher education for students graduating from the academic track. The lack of alternatives might make the transition to higher education especially important.

10. If both parents are present we measure the education level of the parent who has the highest education. If only one parent is present we use information on the parent who is present. For 13.2 percent of the ethnic minority (2.3 percent of the total sample) there are no information on parents education. Students with missing family education are grouped together with students with the lowest family education. We have tested analyses where those with missing family education is excluded, analyses where they are treated as a separate group and analyses where all first generation immigrants (who have the highest proportion missing) are excluded. All versions yield very similar results.

11. The analyses were performed using the MLwiN program (version 2.0).

12. Control for graduation year, interaction between ethnic composition and socio-economic background, and interaction between ethnic composition and minority girls are tested, but did not yield significant results.

13. 'Sigma e' is not stated in Table 3 because there is no useful interpretation of this measure in logistic multilevel analyses.

14. In a Scandinavian context, we can find some indirect support for our results in previous studies. Blom (2002) finds that the proportion of immigrants in an area has little effect on integration. In a comparative study of 20 countries, Marks (2005) finds that Norway is among the countries where average school performance seems to matter the least for the school performance of minority students. Dryler (2001) finds that, in 1997, ethnic composition in compulsory school in Sweden does not affect the 
students' grade average. Although students from schools with a high proportion of minority students have a higher risk of obtaining low or incomplete grades, they also have a higher probability of continuing in non-vocational tracks in upper secondary school. But a study of the comprehensive schools in Sweden does show contextual effects related to ethnic segregation. (Szulkin and Jonsson, 2005).

15. A recent Norwegian master thesis indicates that obtaining good grades might be easier in comprehensive schools with many minority students (Losnegaard, 2006).

\section{Acknowledgements}

This study is part of the research project Educational Careers: Attainment, Qualifications and Transitions to Work, financed by the Norwegian Research Council. An earlier version of this article was presented at a workshop of the EQUALSOC (EU Network of Excellence) in Mannheim, 2-3 December 2005, and at the Sociology seminar at the Department of Sociology, University of Oxford, 20 February 2006. We appreciate comments from participants at these seminars, as well as Idunn Brekke, David Cox, John Eriksen, Gaute Losnegaard, Marianne Nordli Hansen, Arne Mastekaasa, Øyvind Wiborg, Oslo kommune, and ESR's anonymous reviewers.

\section{References}

Bakken, A. (2003). Minoritetsspråklig Ungdom i Skolen. Reproduksjon av Ulikhet Eller Sosial Mobilitet? Oslo: NOVA.

Blom, S. (2002). Innvandrernes Bosettingsmønster $i$ Oslo. Oslo: Statistics Norway.

Bonesronning, H., Falch, T. and Strom, J. (2005). Teacher sorting, teacher quality, and student composition. European Economic Review, 49, 457-483.

Borjas, G. J. (1992). Ethnic capital and intergenerational mobility. Quarterly Journal of Economics, 107, 123-150.

Bourdieu, P. (1984). Distinction. A Social Critique of the Judgement of Taste. London: Routledge \& Kegan Paul.

Brochmann, G. (2003). Del II. 1975-2000. In Kjeldstadli, K. (Ed.) Norsk innvandringshistorie 3: I globaliseringens Tid. 1940-2000. Oslo: Pax.
Chang, M. J. (2000). The relationship of high school characteristics to the selection of undergraduate students for admission to the University of California-Berkeley. Journal of Negro Education, 69, 49-59.

Coleman, J. S. (1966). Equality of Educational Opportunity. Washington: U.S. Department of Health Education and Welfare.

Crain, R. L. and Mahard, R. E. (1978). Desegregation and black-achievement - Review of the Research. Law and Contemporary Problems, 42, 17-56.

Crain, R. L. and Mahard, R. E. (1983). The effect of research methodology on desegregationachievement studies - a Meta-Analysis. American Journal of Sociology, 88, 839-854.

Dryler, H. (2001). Etnisk Segregation i Skolan. SOU 2001:57. Stockholm: Fritzes.

Engen, T. O., Sand, S. and Kulbrandstad, L. A. (1997). Til keiseren hva keiserens er? Om minoritetselevenes utdanningsstrategier og skoleprestasjoner. Sluttrapport fra prosjektet "Minoritetselevers skoleprestasjoner". Vallset: Oplandske bokforlag.

Erikson, R. and Jonsson, J. O. (1996). Can Education be Equalized?. Boulder, Colorado: Westview Press.

Fekjær, S. (2006). Utdanning hos annengenerasjon etniske minoriteter i Norge. Tidsskrift for samfunnsforskning, 47, 57-93.

Goldstein, H. (1997). Methods in school effectiveness research. School Effectiveness and School Improvement, 8, 369-395.

Hagen, K., Vogt, P. and Djuve, A. B. (1994). Oslo den delte byen? Oslo: Fafo.

Hallinan, M. T. (2001). Sociological perspectives on black-white inequalities in American schooling. Sociology of Education, 74, 50-70.

Hansen, M. N. (1997). Social and economic inequality in the educational career: do the effects of social background characteristics decline?. European Sociological Review, 13, 305-321.

Jencks, C., Smith, M., Acland, H., Bane, M. J., Cohen, D., Gintis, H., Heyns, B. and Michelson, S. (1972). Inequality. A reassessment of the effect of family and schooling in America. New York: Basic Books.

Johnson, M. K., Crosnoe, R. and Elder, G. H. (2001). Students' attachment and academic engagement: the role of race and ethnicity. Sociology of Education, 74, 318-340.

Kanter, R. M. (1977). Some effects of proportions on group life - skewed sex-ratios and responses to token women. American Journal of Sociology, 82, 965-990. 
Kristen, C. (2002). Hauptschule, realschule oder gymnasium? ethnische unterschiede am ersten bildungsübergang. Kölner Zeitschrift für Soziologie und Sozialpsychologie, 54, 534-552.

Lauglo, J. (2000). Social capital trumping class and cultural capital? Engagement with school among immigrant youth. In Baron, S., Field, J. and Schuller, T. (Eds) Social Capital: Critical Perspectives. Oxford: Oxford University Press.

Losnegaard, G. (2006). Etnisk sammensetning og skoleprestasjoner. En flernivåanalyse av 48 ungdomsskoler $i$ Oslo. Master thesis. Oslo: Department of Sociology and Human Geography, University of Oslo.

Marks, G. N. (2005). Accounting for immigrant nonimmigrant differences in reading and mathematics in twenty countries. Ethnic and Racial Studies, 28, 925-946.

Mayer, S. E. and Jencks, C. (1989). Growing up in poor neighborhoods - how much does it matter. Science, 243, 1441-1445.

Ogbu, J. U. (1991). Immigrant and involuntary minorities in comparative perspective. In Gibson, M. A. and Ogbu, J. U. (Eds) Minority Status and Schooling. A Comparative Study of Immigrant and Involuntary Minorities. New York: Garland Publishing, Inc.

Oslo kommune (2005). Skolekatalogen 2005. <http:// www.utdanningsetaten.oslo.kommune.no/osloskoler/ videregaende_skoler/inntak/skolekatalogen/ article35816-10175.html> [accessed 13 June 2005].

PISA(2004). Programme for International Student Assessment: Learning for tomorrows world. First results from PISA 2003. Paris: OECD.

Portes, A. and Hao, L. X. (2004). The schooling of children of immigrants: Contextual effects on the educational attainment of the second generation. Proceedings of the National Academy of Sciences of the United States of America, 101, 11920-11927.

Portes, A. and Rumbaut, R. G. (2001). Legacies. The Story of the Immigrant Second Generation. Berkeley, California: University of California Press.

Rutter, M. and Maughan, B. (2002). School effectiveness findings 1979-2002. Journal of School Psychology, 40, 451-475.

Ryan, A. M. (2000). Peer groups as a context for the socialization of adolescents' motivation, engagement, and achievement in school. Educational Psychologist, 35, 101-111.

Shavit, Y. and Blossfeld, H. P. (1993). Persistent Inequality. Changing Educational Attainment in Thirteen Countries. Boulder, Colorado: Westview Press.
Snijders, T. A. B. and Bosker, R. J. (1999). Multilevel Analysis. An Introduction to Basic and Advanced Multilevel Modeling. London: Sage.

SSB (2005). Innvandrerbefolkningen. Statistics Norway. $<$ http://www.ssb.no/emner/02/01/10/innvbef/tab2005-05-26-13.html > [accessed 16 August 2005].

Szulkin, R. and Jonsson, J. O. (2005). Immigration, Ethnic Segregation and Educational Outcomes: A Multilevel Analysis of Swedish Comprehensive Schools. Paper presented at the PAA meeting in Philadelphia, April 2005.

Teranishi, R., Allen, W. R. and Solorzano, D. G. (2004). Opportunity at the crossroads: Racial inequality, school segregation, and higher education in California. Teachers College Record, 106, 2224-2245.

Thomas, G. E. and Brown, F. (1982). What does educational-research tell us about schooldesegregation effects. Journal of Black Studies, 13, $155-174$.

TV2 (2003). Ghettoskolen. <http://pub.tv2.no/TV2/ magasiner/dokument2/article146459.ece $>$ [accessed 3 February 2004].

Van der Slik, F. W. P., Driessen, G. W. J. M. and De Bot, K. L. J. (2006). Ethnic and socioeconomic class composition and language proficiency. A longitudinal multilevel examination in Dutch elementary schools. European Sociological Review, 22, 293-308.

Willis, P. E. (1977). Learning to Labour. How Working Class Kids Get Working Class Jobs. Farnborough: Saxon House.

Wortman, P. M. and Bryant, F. B. (1985). Schooldesegregation and black-achievement —an integrative review. Sociological Methods \& Research, 13, 289-324.

Østby, L. (Ed.) (2004). Innvandrere i Norge - Hvem er de, og hvordan går det med dem? Oslo: Statistics Norway.

\section{Author's Address}

Silje Noack Fekjær (to whom correspondence should be addressed), Department of Sociology and Human Geography, University of Oslo, Boks 1096 Blindern, 0317 Oslo, Norway.

Email: fekjar@sosiologi.uio.no

Manuscript received: March 2006 